\title{
Is Judicial Remedy Effective in Resolving Collective Labor Disputes in China?-Based on 622 Cases $^{1}$
}

\author{
LI Xiang \\ South China Normal University, Guangzhou, China
}

\begin{abstract}
Collective labor disputes connect a group interests of workers and employers, and the settlement of which directly affects working conditions of a specific enterprise or industry. The increasing number of labor disputes in China indicates that not all grievances of workers are handled successfully. Judicial remedy is the last guardian of workers' rights and interests. However, little research provides a quantitative analysis concerning the effectiveness of judicial remedy in resolving collective labor disputes. By investigating 622 cases, this paper finds that workers mostly won cases involving economic rights, but lost cases where strict procedures are required. Judges' active tendency of separating disputes and the limited access to judicial resources drive workers with institutional demands or interest-based disputes to express their dissatisfactions in an irrational way. This is mainly caused by flawed legislation which unproperly defines collective labor disputes and fails to channel workers' collective actions in a reasonable way. To better protect the rights and interest of workers, the legislation shall be revised, specifically, enlarging scopes and simplifying procedures of judicial remedies.
\end{abstract}

Keywords: China, collective labor disputes, judicial remedy, labor law

\section{Introduction}

Accompanied with the transformation from a planned economy to a market economy in China, the ownership of enterprises has been diversified. This stimulates the surge of collective labor disputes. The existing literature implies that present mechanisms of resolving are problematical, time-consuming, lack of independence, and filled with conspiracy. Mediation agencies have not yet been established in most enterprises, and where they have, the process tends to be a mere formality (Cooke, 2013). The arbitration-litigation system of a simple dispute can stretch over two years, as the fieldwork of Li and Liu (2016, p. 295) demonstrated. In addition, there are other "invisible hurdles" preventing workers from choosing arbitration or litigation. For instance, Chen and Xu (2012) and Friedman (2014) contend that in judicial practice, workers' power is often dispersed: The courts and arbitration systems would prefer to split collective disputes into individual cases. Furthermore, arbitration agencies and courts at the local level are often regarded more influenced by corresponding local governments, which tend to exert their administrative power in order to create a pro-business environment (Friedman \& Lee, 2010, p. 518; Cooke, 2013).

Previous research is mostly based on qualitative analysis; little research explores to what extent judicial

\footnotetext{
LI Xiang, Dr., associate researcher of Law School, South China Normal University, Guangzhou, China.

1 The original version of this paper was accepted by the 18th International Labor and Employment Relations Association (ILERA) World Congress which was held in Seoul.
} 
remedy is effective in resolving collective labor dispute through quantitative analysis. By investigating 622 cases, this paper tries to respond to this question. The cases are from Chinese Judgements Online and China Court (till December 1, 2019), which are official records providing precise information on collective labor disputes ending with litigation. This paper firstly reviews the law to provide basic knowledge concerning how collective labor disputes are channeled by law. Thereafter, 622 cases are analyzed, including how cases are handled, the distribution of workers' demands, and the outcomes. Then this paper discusses the reasons and impacts for the findings, followed by certain suggestions for legislation modification.

\section{A Review of Legislation Concerning the Lawful Remedy}

Since 2007, a series of laws have been passed, which are specially designed to adjust labor disputes, for instance, Labor Dispute Mediation and Arbitration Law of the People's Republic of China (2007), Provisions on the Negotiation and Mediation of Enterprise Labor Disputes (2011), Rules of Handling Cases Related to Labour and Human Resources Labor Disputes Arbitration (2017). These regulations indicate that legislators are re-building labor dispute resolution mechanisms. ${ }^{2}$ Two local regulations are also worthy to be mentioned, since they are widely accepted as advanced compared with local regulations at a parallel level. They are Shenzhen Special Economic Zone on the Promotion of the Harmonious Labor Relations and The Provisions on Collective Contracts of Guangdong Province (2015). The former almost admits the right to strikes (Article 52).

According to these regulations, four types of mechanisms are regulated to handle with collective labor disputes: mediation, consultation, arbitration, and litigation. The procedures of consultation and mediation are optional, reflecting legislators' preference for resolving labor disputes peacefully, in keeping with the political slogan of "building a harmonious society". Arbitration is a compulsory procedure if workers want to seek justice from the court system.

The present labor law system is mainly used to protect labor rights and resolve labor disputes where individual workers involved. The law concerning collective labor disputes is insufficient and ambiguous. Indifferent from the concept of "collective labor disputes" in western sense, which refers to labor disputes where an employer, or employer association and trade unions, or employee's organization is involved, in Chinese legal context, this concept means disputes involving more than 10 workers with shared grievances and disputes arising in connection with collective labor contracts. ${ }^{3}$ However, there are no clear regulations stating that Chinese judges and arbitrators are obligated to define a labor dispute that involves more than 10 workers sharing a claim as "collective" dispute. This leaves judges some space for manipulation.

\section{Quantitative Analysis}

Similar with existing literature, this paper also finds that there is a tendency that judges split collective cases, which shall be defined as "collective" in arbitration procedures, into individual ones. Among the 626 cases, a majority of them shall be defined as "collective" according to the concept in Chinese legal context. For instance, a judge of Huben Province divided a case where more than 131 workers share same demands into more than 131 individual cases. This "conspiracy theory" is also supported by official data from the China Statistical

\footnotetext{
${ }^{2}$ The year of 1993 witnessed the first series of regulation concerning the labor disputes arising in marketization. These regulations have been more or less abolished until 2011 following the appearance of the recent laws since 2007.

3 Article 7 of the Law of the People's Republic of China on Labour-Dispute Mediation and Arbitration (2008); Article 5 of the Rules of Handling Cases Related to Labor and Human Resources Labor Disputes Arbitration (2017).
} 
Yearbook, which demonstrates that the number of accepted labor disputes has increased from 48,121 in 1996 to 785,323 in 2017, while the number of persons involved in each dispute has decreased from 3.93 in 1996 to 1.25 in $2017 .^{4}$

Workers' demands vary from instant (e.g., wage arrears and compensation) to long-lasting items (social insurance). In 242 cases, workers demanded compensation for terminating labor contract or other illegal behaviors. Social insurance was also one of major demands of workers, where it was demanded in 229 cases. Occasionally, workers even asked double amount of monthly wage for the lack of written labor contract. Only 138 cases were about wage arrears. This may be partly explained by an increasing extent of employers' compliance with the law and paying salaries in time. This also indicates that workers' rights awareness has been improved and they have more detailed knowledge about labor rights.

Concerning the result of lawsuits, workers mostly won the cases regarding substantive rights, such as wage arrears, social insurance, compensations of dismissal. In contrast, workers mostly lost cases in which strict procedures were required. For instance, during 125 cases of Gansu Province, workers demanded the defining of employment relations and the payment of salaries. The workers firstly asked arbitration agencies for addressing grievances but were rejected by the agencies for the expiration of limitation period, and then the workers sought resort from the court of first instances which basically denied most of their demands for the same reason. A few workers still did not agree with the judgements of the courts of first instance and then asked the courts of second instance for justice. However, the latter thoroughly maintained the judgements made by the courts of first instances. ${ }^{5}$ It usually took workers more than one year to go through the whole judicial procedures to seek justice; occasionally, it even consumed two years.

\section{Reasons and Impacts}

The rise of the number of labor disputes suggests that Chinese works are not as silent as in the past. They are increasingly aware of their rights. This is inseparable from their improved qualities (e.g., education backgrounds), and the spread of internet, which facilitates Chinese workers to access the knowledge of law. Chinese labor law is basically favorable to workers' individual rights. Cooney (2007, p. 674) even argues that the individual labor standards established in China "are not markedly inferior to those of comparable countries and indeed many developed countries". Judges are also willing to enforce labor law when employers' faults are obvious and when workers' demands are only about economic items. Workers have benefited from the judgements, because most of their requests are supported.

When the improved rights awareness of workers confronts with judges' tendency to split "collective labor cases" into individual ones, workers' power is largely diluted and they have less chance to win. Such division attributes to both unclear legislation and political influence. Present labor law only admits the existence of work stoppage in China, but keeps silent on whether workers enjoy the right to strike. ${ }^{6}$ The term "strike" (bagong) appears rarely in official documents. In labor law, such terms as "work stoppage" (tinggong) or "slow-down" (daigong) are used instead. For a long time, collective labor disputes, especially those in accompany with strikes or demonstrations, are often defined and treated as "sudden incidents", "mass incidents", which are

\footnotetext{
${ }_{5}^{4}$ See China Statistical Yearbook, available at http://www.stats.gov.cn/tjsj/ndsj/2018/indexeh.htm, last visited on January 7, 2020.

5 For instance, the judgement of (2019) Ning 0104 Min Chu No. 9211.

6 Article 27 of Trade Union Law (1992).
} 
explained as "internal contradictions among the people". This reflects the influence of politics in defining collective labor disputes. Policy-makers fail to distinguish workers' strikes from other collective actions, which are seen as one destabilizing force. In Opinions on Building Harmonious Labor Relationship (2015), the term "work stoppage" is distinguished from "mass incidents" for the first time. Ambiguous legislation allows courts considerable space for operation to divide workers and dissolve collective disputes. Echoing to the political slogan of "maintaining stability", Chinese judges prefer to actively dismantle collective labor disputes, and atomize the participants involved to prevent workers' actions from escalating.

The demands of workers in litigation are mostly related to lawful rights, specifically, economic compensation, etc. This is because that only disputes connected with economic rights are allowed to enter into legal proceedings. How to resolve interest-based labor disputes, such as pay rise, has not been regulated. In addition, the law is also unclear concerning how to address grievance when workers have institutional demands, e.g., direct election of trade unions. The insufficient legislation expels workers who have these demands to voice their grievance by collective actions, such as Honda Strike in 2010. On 17 May 2010, two workers at the Honda Auto Parts Manufacturing Ltd. (CHAM) in Nanhai District, Foshan City, called out to others on the assembly line, "Our wages are so low; let's stop working!" From an initial number of 50 workers, the strike spread to the whole factory and eventually paralyzed Honda's operations throughout China for 17 days, causing the company a loss of $¥ 240$ million a day. In the end, an agreement was reached under which workers’ monthly wages were increased from $¥ 1,544$ to $¥ 2,044$ and intern students’ wages from about $¥ 900$ to around $¥ 1,500$. As this case shows, workers' collective actions emerge suddenly, and vanish quickly. Workers' requirements in collective actions are inclusive, which vary from rights-based disputes (e.g., wage arrears and social insurance) to interests-based disputes (e.g., higher salaries and lower working intensity). There are also examples where workers protest when trade union official fails to fulfil the duty of representing workers ( $\mathrm{Li} \& \mathrm{Liu}, 2016$ ). Compared with judicial remedies, workers' collective actions cost less time, less money, but there are possibilities to achieve their demands. Workers may not succeed through collective actions, but several days of stoppage always bring huge loss to employers.

It is noticeable that workers mostly failed in cases involving procedural rights. This means that workers are only roughly aware that employing entities break the law and intend to defend their rights by taking awful weapons, whereas, they have less knowledge about legal procedures. Limitation period is an important element and a precondition for workers to fulfill their demands in lawsuits. The period is usually statutory and after that employees' rights of applying for arbitration for redressing will not be protected by law and lose the chance to win. The time limitation period for application for arbitration of a labor dispute is one year, and it shall be counted "as of the date when a party knows or should know that its right has been violated..." regulated by Labor Law, ${ }^{9}$ one year of limitation period is already a remarkable progress approaching workers' side, whereas, it is still impracticable for workers to grasp the law as skillfully and precisely as lawyers. This is due to the fact that Chinese workers, especially migrant workers, are less educated. In the cases collected by the author $^{10}$, when workers asked arbitration agencies for help, it is already more than four years after the termination of the labor contract. Thus, neither the courts of first or second instances supported the workers' demands.

\footnotetext{
${ }^{7}$ See Opinions on the Work of Actively Preventing and Appropriately Handling Mass Incidents (2004).

8 Article 27 of Labor Dispute Mediation and Arbitration Law of the People's Republic of China.

9 Article 82 of Labor Law (1994).

${ }^{10}$ For instance, the judgements of (2016) Gan 04 Min Zhong No. 311\& (2016) 0627 Min Chu No. 500.
} 
Workers' insufficient knowledge on the law and the lack of practicality of legislation are two reasons for the failure, which undermine workers' willingness to ask for lawful remedies. Additionally, when resolving labor disputes through judicial methods, workers have to provide the evidence of the abuse of their rights, or the breach of labor contract. These tasks are difficult to achieve since they have little chance to access the documents of the enterprise they work. Such difficulty also discourages workers' willingness and becomes an invisible hurdle for workers to seek justice from law.

\section{Conclusions}

As suggested by quantitative analysis, judicial remedy is mainly effective when employers obviously violate the law, and when workers' demands only involve economic items. Despite winning the cases, legal proceedings are time-consuming, and it remains unopen to cases concerning non-regulated interests or institutional reform. Besides, workers' determinations to use lawful weapons are also undermined by judges' active tendency of splitting cases, inadequate knowledge concerning procedural rights, etc. Flawed legislation is responsible for the status quo. Once a labor contract is conducted, a worker has to subordinate to employers' management and control, and then has less power to countervail the pressure from employers. Judicial remedy is the last guardian of workers' rights and interests. If the last lawful weapon (litigation) could not offer workers a feasible way to address their grievance, workers have to take collective actions, such as strikes, blocking highways, which may result in social unrest and the cost of companies' profits. To better improve working conditions and reduce workers' spontaneous actions, the law should clarify definitions, enlarge scopes, ameliorate civil proceedings of collective labor disputes.

Under the backgrounds of flawed legislation, judges actively divide collective labor disputes into individual ones, and workers easily feel defenseless when facing employers' power as individuals due to their subordination to employers. To forming countervailing power, a "collective unit", which is elected democratically by workers and with professional bargaining skills, is needed. Correspondingly, the law shall regulate procedures of electing representing agents of workers and clarify obligations and rights of such representing agents. To prevent relevant regulations from being hollow and unenforceable, remedy mechanisms shall also be mapped out when the agents fail to perform duties. Under this context, handling labor cases collectively is both beneficial to save judicial resources and contain social unrest.

The regulation of one year of limitation period fails to meet the principle of labor law, which is protecting the rights and interests of workers. The period is even shorter than that of civil dispute resolution, the parties involved which are equal but still have two years for relief when their rights are infringed upon. Employers and workers are equal when conducting labor contracts, whereas, once they are on board, they are under the control and management of employers, and then the dual parties are also unequal. To echo the principle of Labor Law, which is protecting the rights and interests of workers, the period which workers are able to assert their rights shall be equal or longer than two years, and cases concerning wage arrears shall not be restricted by regulations on periods given workers' subordination to employers during employment. Additionally, present law is unclear on who has the rights to claim that the period is expired. This leaves judges and arbitrators some space for operation and occasionally; they even actively deny workers' litigation for this reason. Such judgements are abuse of judicial power. Future legislation shall forbid judges' active investigation of the period. Additionally, the arbitration-litigation system is time-consuming, and it is one of main reasons that workers do not seek justice from the law. The law shall simplify the procedures of judicial remedies. 
The modification of the law is necessary, but it does not mean that revised legislation can immediately bring a higher effectiveness of litigation. This is because the effectiveness is also affected by other factors, such as judges and workers' personal qualities, the Chinese culture of the disgrace of litigation, and the various levels of economic development across China. The law can only provide institutional supports for workers to take lawful weapons. The improvement of workers' rights and interests relies more on judges, employers, and workers' compliance with the law.

\section{References}

Cooke, F. L. (2013). New dynamics of industrial conflicts in China: Causes, expressions and resolution alternatives. In G. Gall (Ed.), New forms and expressions of conflict at work (pp. 108-129). Cheltenham: Edward Elgar.

Cooney, S. (2007). China's labour law, compliance and flaws in implementing institutions. Journal of Industrial Relations, 49(5), 673-686.

Chen, F., \& Xu, X. (2012). "Actively judiciary”: Judicial dismantling of workers' collective action in China. The China Journal, $67,87-108$.

Chen, F. (2007). Individual rights and collective rights: Labor's predicament in China. Communist and Post-Communist Studies, 40, 59-79.

Friedman, E. (2014). Insurgence trap: Labor politics in postsocialist China. Ithaca: Cornell University Press.

Friedman, E., \& Lee, C. K. (2010). Remaking the world of Chinese labor: A 30-year retrospective. British Journal of Industrial Relations, 48(3), 507-533.

Li, C. Y., \& Liu, M. W. (2016). A pathway to a vital labor movement in China? A case study of a union-led protest against Walmart. In M. W. Liu and C. Smith (Eds.), China at work, a labour process perspective on the transformation of work and employment in China (pp. 281-311). New York: Macmillan Palgrave UK. 